REVIEWS

UDC 577.21

\title{
Nucleosomal packaging of eukaryotic DNA and regulation of transcription
}

\author{
A. K. Golov ${ }^{1}$, S. V. Razin ${ }^{1,2}$, A. A. Gavrilov ${ }^{1}$ \\ ${ }^{1}$ Institute of Gene Biology, Russian Academy of Sciences \\ 34/5, Vavilov Str., Moscow, Russian Federation, 119334 \\ ${ }^{2}$ Faculty of Biology, M. V. Lomonosov Moscow State University \\ 1/12, Vorobyovi gory, Moscow, Russian Federation, 119991 \\ aleksey.a.gavrilov@gmail.com
}

\begin{abstract}
The eukaryotic nucleus harbors genomic DNA, which is tens of thousands of times greater in linear size than the nuclear diameter. Its high condensation is due to DNA packaging in chromatin, and DNA wrapping around nucleosomal globules is a key step in the process. A histone octamer, which forms the nucleosomal globule, interacts with DNA via electrostatic contacts. DNA-histone interactions are rather tight and prevent nucleosomal DNA from being accessed by various enzymes and transcription factors. At the same time, nucleosomes do not prevent transcription and other processes related to the genetic function of DNA. The review considers the structure and diversity of nucleosomes and the central role they play in regulating transcription. Special emphasis is placed on how internucleosomal interactions contribute to genome accessibility to transcription machinery and how nucleosomes are removed from regulatory elements and transcription units in a controlled manner during transcription elongation.
\end{abstract}

Keywords: chromatin, histone modifications, nucleosome, transcription.

Introduction. Histones are among the most conserved eukaryotic proteins [1]. The mere fact points to an extremely important role they play in the eukaryotic cell. For a long time, studies of histones and chromatin focused primarily on the structural aspect, elucidating how DNA is compactly packaged in the nucleus [2]. However, the role nucleosomes may play in regulating differential gene expression and other processes related to the genome function came into consideration almost as soon as nucleosomes were discovered [3]. It is beyond doubt now that several regulatory mechanisms work at the level of DNA packaging in chromatin to control various aspects of genome function, including the so-called epigenetic memory mechanisms, which play a key role in establishing the identity of differentiated cells. The transcription-regulating role of nucleosomes is a main focus of this review. Special emphasis is placed on how the nucleosome structure and positioning on DNA are

(C) Institute of Molecular Biology and Genetics, NAS of Ukraine, 2014 associated with the regulation of transcription. A limited number of model loci - such as the beta-globin genes of vertebrates or PHO5, GAL1-10, and HIS3 of yeasts - were used for many years to study functional activity of the genome organized in chromatin. The results obtained with the model systems were extrapolated to the whole genome. High-throughput sequencing technology developed in the past decade allowed a number of methods, such as ChIP-seq, Dnase-seq, and others, to be used to verify the structural-functional correlations at the whole genome level. We have tried to involve these new data wherever possible.

First, the structures of the basic nucleosomal particle and 10-nm chromatin fiber, which is composed of nucleosomes, are briefly considered in the review. Then we discuss the modern data that indicate a lack of regular interactions between nucleosomal particles in the eukaryotic nucleus. Emphasis is placed on the specifics of nucleosome positioning on DNA and primarily on nucleosome-free regions, which usually harbor 
various regulatory elements of the genome. Transcription of nucleosomal DNA is also considered. The final part describes the current views of the modulation of internucleosomal interactions and its role in regulating transcription.

Nucleosome fiber is a basic structure of chromatin. The 10-nm nucleosome fiber is the level of DNA packaging in chromatin that is best understood now [4, 5]. The fiber is a DNA molecule interacting regularly with protein globules known as the nucleosome cores. A DNA region of 145-147 bp is wrapped around each globule. The DNA region forms 1.65 left-handed superhelical turns. The globule consists of eight core histones. Having a modular organization, the globule is a complex of an (H3-H4) tetramer and two H2A-H2B dimers [6]. The structure of a nucleosomal particle (a core with DNA wrapped around it) was solved to $1.9 \AA$ by X-ray analysis [7]. The histones of the octamer are organized in a left-handed helix, which sterically matches the superhelical turns of the wrapping DNA fragment. The histone arrangement along the DNA molecule is as follows: the H2A-H2B dimers contact DNA at the entry and exit of the nucleosomal particle, while the $(\mathrm{H} 3-\mathrm{H} 4)_{2}$ tetramer contacts the central part of the DNA region wrapped around the nucleosomal globule. The nucleotide sequence-independent interaction of the nucleosome core with DNA is due to ionic, hydrogen, and hydrophobic bonding of the proteins with the DNA sugar-phosphate backbone. Two structural and functional domains are recognized in the core histones. The domains are a histone tail $(\sim 20-35$ nonstructured N-terminal amino acid residues) and a histone fold (the other $\sim 80-100$ residues), which consists of three $\alpha$-helical regions linked by small loops. Two short (10-14 residues each) helices of the histone fold flank a longer helix, which consists of 28 residues. Along with additional secondary structure elements unique to each of the core histones, the histone fold ensures the majority of histone interactions with nucleosomal DNA and other histones. A DNA region between two neighbor nucleosomes is known as the linker and varies from 10 to $90 \mathrm{bp}$ among different organisms, different cells, and different genome regions [8]. Histone H1, which substantially differs in both size and structure from the core histones, can bind to the linker at the nucleosome entry-exit sites, thus closing two full superhelical turns. Histone H1 is presumably involved in maintaining the supranucleosomal packaging levels $[9,10]$. The nucleosome fiber is a basic structure of eukaryotic chromatin. The only exceptions are dinoflagellate chromatin [11] and male gamete chromatin in many eukaryotic groups, including mammals [12].

A conserved character was emphasized for nucleosomal particles over many years. Now it is clear that nucleosomes are not all identical. Modified nucleosome forms occur along with canonical nucleosomes in chromatin. To produce these forms, variant histones are incorporated in nucleosomes and posttranslational modifications made to histones of the nucleosomal globule. More than one hundred of posttranslational modifications have been observed in histones to date [13, 14], of which the best known are acetylation (at lysines), methylation (at lysines, arginines, and histidines), phosphorylation (at serines), poly-ADP-ribosylation (at glutamates), ubiquitination, and SUMOylation (at lysines). Proline cis-trans isomerization is also possible. The development of new methods, especially those based on mass spectrometry [15], allowed the identification of new histone posttranslational modifications, such as $O$-glycosylation at serine and threonine [16], formylation and crotonylation at lysine, and hydroxylation at serine [17].

The main targets of posttranslational modification occur in the nonstructured $\mathrm{N}$-terminal tail domains of histones [13, 14], although exceptions are possible; i. e., several residues acting as targets for functionally important modification are in the globular histone regions [18, 19]. As already mentioned, many variant histones exist along with the canonical one; they are encoded by separate genes and can be incorporated in a nucleosome in place of their canonical counterparts (via a replicationindependent mechanism, while canonical nucleosomes are assembled on newly synthesized DNA molecules). The nucleosomes that incorporate variant histones often differ from canonical nucleosomes to a substantial extent and perform special functions, for example modulate transcriptional activity [20-23] The variant histones characterized most comprehensively include CENP-A (centromeric H3), H3.3, macroH2A, H2A.Bbd, H2A.Z, H2A.X, and H5 (variant H1) [24].

Lateral internucleosomal interactions and the 30nm fiber. It was believed until recently that a nucleoso- 
mal thread folds in vivo to produce a regular structure of $30 \mathrm{~nm}$ in diameter, which is known as the $30-\mathrm{nm}$ fiber. In vitro, these structures form in the presence of histone $\mathrm{H} 1$ or high concentrations of divalent cations [25, 26]. Two main models were advanced for the nucleosome thread folding in the $30-\mathrm{nm}$ fiber. One suggests that the $10-\mathrm{nm}$ fiber folds into a solenoid containing 6 nucleosomes per turn (one-start helix) [25]. According to the other model, a nucleosome thread forms a zigzag structure (two-start helix) [27-29]. Several other, less common models were discussed along with the above ones [30]. While the fine organization of the $30-\mathrm{nm}$ fiber was a matter of dispute, it seemed unquestionable until recently that $30-\mathrm{nm}$ fibers occur in the eukaryotic nucleus. As experimental methods improved and the interpretation of experimental findings was refined, the question arose as to whether 30-nm chromatin fibers actually exist in vivo in both interphase nuclei and metaphase chromosomes [31-34]. A molten polymer model was proposed on the basis of new findings to describe the folding of the 10 -nm fiber in the interphase nucleus [31-33]. The model postulates that the $10-\mathrm{nm}$ fiber produces an irregular dynamic structure via internucleosomal interactions between its distant regions «in trans». This fold is thought to provide for a more plastic chromatin packaging as compared with the $30-\mathrm{nm}$ fiber, thus eventually facilitating all chromatin-related processes [31-33]. The molten polymer model allows spatially close nucleosomes to form the same internucleosomal interactions that were observed for structures like the $30-\mathrm{nm}$ fiber, but the interactions are not regular in the molten polymer, arising and breaking down in a stochastic manner. Indeed, one of the key interactions in the molten polymer is a contact of the N-terminal domain of histone $\mathrm{H} 4$ with an acidic patch of the $\mathrm{H} 2 \mathrm{~A}-$ $\mathrm{H} 2 \mathrm{~B}$ dimer belonging to another nucleosome, that was detected in an X-ray analysis of tetranucleosomes producing a zigzag structure (two-start helix) [28, 35].

Nucleosome depletion is characteristic of active regulatory elements. In spite of their dynamic character [5], nucleosomes prevent, to a certain extent, a free access to DNA for various protein factors [36, 37]. To bind to DNA, the majority of general and specific transcription factors require that the regular nucleosome arrangement on a DNA thread be locally disrupted to generate a nucleosome-free region (NFR) or a nucleoso- me-depleted region (NDR) [38, 39]. The regions are several hundreds of base pairs in size and can be mapped as DNase I-hypersensitive regions [40-42]. Various regulatory elements of the genome usually occur in NFRs and NDRs [43-47]. It is possible to say that, compared with the prokaryotic genome, the eukaryotic genome is repressed on default and that transcription is regulated largely by modulating the genome accessibility to transcription machinery [48, 49].

First, the generation of NFRs and NDRs is necessary for assembly of the preinitiation complex on a promoter [50]; i. e., active promoters are always NDRs [39, 51]. It is typical of higher eukaryotes that chromatin remodeling complexes work to release the promoters from nucleosomes [52, 53], as is considered below. Another strategy is used in the case of Saccharomyces cerevisiae constitutive promoters, where nucleosome occupancy depends to a substantial extent on the DNA sequence $[50,54]$. Although the binding of the nucleosome core to DNA is not sequence specific, there are sequences that more or less preferentially interact with the histone octamer and those where the octamer is usually not assembled. The probability for a nucleosome to land on a particular DNA sequence depends to a great extent on the DNA flexibility, that is, the capability of wrapping around the nucleosomal globule. A poly(dA:dT) tract is one of the sequences that poorly bind with the nucleosome core [55]. A typical constitutive yeast promoter contains a poly $(\mathrm{dA}: \mathrm{dT})$ tract flanked by two sequences that preferentially bind nucleosomes and are known as the nucleosome positioning sequences (NPSs) $[51,56]$. The nucleosome-free region usually harbors binding sites for transcription factors, which recruit transcription initiation proteins to the promoter [57].

A chromatin remodeling strategy is commonly utilized to establish and maintain the NDR in inducible $S$. cerevisiae promoters (TATA-containing promoters) and gene promoters of other eukaryotes examined [50]. A key role is played in this case by active ATP-dependent nucleosome displacement involving chromatin remodeling complexes $[52,53]$. Various chromatin remodeling complexes move the nucleosome cores along a DNA molecule, remove them from DNA, replace canonical histones with variant ones, and perform several other functions. Chromatin remodeling complexes of the SWI/SNF and ISWI families play a main role in es- 
tablishing and maintaining NDRs [58, 59]. NDRs are partly occupied by nucleosomes in $S$. cerevisiae upon depletion of the RSC complex, which belongs to the SWI/SNF family [60]. Transcription factors known as the pioneering factors are the first to initially recruit the chromatin remodeling complexes to cis-regulatory elements to establish an NDR [57, 61]. The pioneering factors differ from the majority of transcription factors in being capable of recognizing their sites on nucleosomal DNA. A small site for a pioneering factor can occur in the linker between two positioned nucleosomes [62, 63]. Other pioneering factors are capable of competing with nucleosomes for binding to DNA [61]. The pioneering factors recruit either chromatin-remodeling complexes or the enzymes that introduce certain posttranslational modifications acting to recruit chromatin remodeling complexes. A primary remodeling of the promoter region can open DNA to the binding of other transcription factors, which similarly facilitate the NDR maintenance and extension [64].

An association between the presence of NDRs and the enrichment of chromatin regions with certain histone marks was demonstrated at the whole-genome level in many studies [39, 65-68]. Among the histone posttranslational modifications that serve to recruit chromatin remodeling complexes, lysine acetylation in the tail domains of histones $\mathrm{H} 3$ and $\mathrm{H} 4$ plays an essential role and is high in active promoters [39, 65-68]. Nucleosomes that incorporate histone $\mathrm{H} 3$ acetylated at $\mathrm{K} 9$ and/or K27 recruit the remodeling complexes with a bromodomain, which recognizes these modifications $[69,70]$. Acetylation additionally acts to increase activity of the complexes recruited [71, 72]. Histone acetyltransferase activity is inherent in many conserved coactivator complexes, including SAGA, p300/CBP, and TAF1 [73-75].

Along with high-level acetylation, the incorporation of variant histones H2A.Z and H3.3 in the vicinity of an NDR seems to contribute substantially to nucleosome depletion from active promoters $[65,76]$. Nucleosomes with H2A.Z and H3.3 are less stable [77] and facilitate the NDR maintenance by chromatin remodeling complexes [78]. According to recent data, such nucleosomes are almost always present within NDRs as well, being easily displaced from DNA by certain protein factors [21]. The H2A-H2B dimers are replaced with the
H2A.Z-H2B dimers by the Swr1 complex of the SWI/ SNF family in yeasts (and by its orthologs SRCAP and p400 in Metazoa) [79, 80]. Swr1 is recruited to acetyla ted nucleosomes and has affinity for nucleosome-free DNA [81].

Enrichment in $\mathrm{H} 3 \mathrm{~K} 4 \mathrm{me} 3$ is one of the most distinct features of active promoters [39, 65-68]. The modification probably maintains NDRs apart from its other putative functions [82]. A characteristic location of $\mathrm{H} 3 \mathrm{~K} 4 \mathrm{me} 3$ in the 5 regions of genes is related to the mechanism of this modification. Histone methyltransferase Set1, which is conserved among all eukaryotes and is responsible for $\mathrm{H} 3 \mathrm{~K} 4$ trimethylation, binds to the Ser5-phosphorylated C-terminal domain of initiating RNA polymerase [83, 84]. As the polymerase starts elongation and the posttranslational modification profile of its C-terminal domain changes (phosphorylation at Ser2 rather than at Ser5), Set1 dissociates, and the level of H3K4 methylation grows lower [36, 85]. A transcription-independent mechanism is also possible for H3K4 methylation in vertebrates. In vertebrates, Set1 is recruited to the promoters of housekeeping genes and master regulators of cell differentiation by Cfp1: the promoters occur in $\mathrm{CpG}$ islands, $\mathrm{Cfp} 1$ is capable of recognizing nonmethylated $\mathrm{CpG}$ dinucleotides, and both Cfp 1 and Set1 are components of one complex, COMPASS $[86,87]$. Many chromatin remodeling complexes have protein components that interact with $\mathrm{H} 3 \mathrm{~K} 4 \mathrm{me} 3$ (this modification is recognized by the PDH, Chromo, Tudor, MBT, and Zf-CW domains of various proteins [88]). For instance, H3K4me3-binding domains are responsible for the recruitment to promoters of human proteins CHD1 and BPTF, which are components of chromatin remodeling complexes and have homologs in many eukaryotes [89]. Histone acetyltransferases (HATs) contained in the SAGA and NuA3 complexes are similarly recruited to promoters as other components of the complexes interact with H3K4me3 [90].

In higher eukaryotes, NDRs are associated not only with promoters, but also with transcription factor-binding sites located in distant regulatory DNA elements, of which enhancers and insulators are two main classes. Distant regulatory elements, rather than promoters, account for the vast majority of regions where NDRs are established in some or other cells in Metazoa [39, 66, 91]. Enhancers are sequences of several hundreds of ba- 
se pairs in length and harbor binding sites for several transcription factors, which are responsible for specific activation of enhancer-regulated genes $[92,93]$. Enhancers can be up to tens or hundreds of kilobases away from their target promoters $[39,66,94]$. The distance is even greater than $1 \mathrm{Mb}$ in exceptional cases [95]. Enhancers can occur both upstream and downstream of the target promoters, in both intergenic regions and introns $[96,97]$. Cases were documented where enhancers are in coding gene regions [98].

Enhancer NDRs are far more tissue specific than promoter-associated NDRs [39, 66, 99]. A close relationship is assumed for the establishment of NDR and the establishment of the enhancer-associated H3K4me1 mark at enhancers $[39,65,66,68]$. Pioneering factors recruit histone methyltransferases, which establish an H3K4me1-enriched region at the enhancer [100]. In turn, $\mathrm{H} 3 \mathrm{~K} 4 \mathrm{me} 1$ recruits the $\mathrm{p} 400$ remodeling complex, which incorporates H2A.Z in nucleosomes [101, 102]. H2A.Z-containing nucleosomes are unstable, and a small NDR consequently forms at the so-called poised enhancers $[99,103,104]$. Differentiation signals activate the poised enhancers by targeting additional tissuespecific transcription factors and signaling pathway effectors to them, and the factors expand the NDR by recruiting and activating the chromatin remodeling and coactivator complexes possessing HAT activity, including $\mathrm{p} 300 / \mathrm{CBP}$ as a main one $[93,105]$. A main target of p300/CBP is $\mathrm{H} 3 \mathrm{~K} 27$, and its acetylation is thought to provide a mark associated with active enhancers [99, 103].

Along with enhancers, cis-regulatory elements known as the insulators colocalize with nonpromoter NDRs. Insulators are thought to perform a broad range of functions, the main of which are to prevent the extension of repressive chromatin marks (barrier activity) and to block the action of an enhancer on a promoter when interposed between them (enhancer-blocking activity) [106-108]. Insulators can display either both activities or exclusively enhancer-blocking activity in a transgenic reporter assay. Enhancer-blocking activity is due to binding sites for a special protein group known as the insulator proteins. TFIIIC is one of the most conserved insulator proteins, acting additionally as a general transcription factor to facilitate RNA polymerase III landing on DNA $[109,110]$. CTCF also performs the insulator function in vertebrates $[111,112]$. Drosophila has not only TFIIIC and a homolog of vertebrate CTCF (dCTCF) to sustain enhancer-blocking activity of insulators, but also a number of other proteins: $\mathrm{Su}(\mathrm{Hw})$, GAF, BEAF-32, and Zw5 [113, 114].

Insulator NDRs are enriched in $\mathrm{H} 3 \mathrm{~K} 4 \mathrm{me} 1$ and the H2A.Z variant $[68,115]$. The mechanism that establishes and maintains NDRs at insulators is most likely similar to that of enhancers. It should be noted that vertebrate insulators are less variable than enhancers and that their positions are more or less constant in different cells [66]. This is possibly related to the fact that the main vertebrate insulator protein CTCF occurs in all cells and acts as a pioneering factor, autonomously binding to its sites in chromatin regardless of whether or not they are free of nucleosomes $[61,116]$.

Several insulators and enhancers display RNA polymerase II binding and enrichment in $\mathrm{H} 3 \mathrm{~K} 4 \mathrm{me} 3$, thus being functionally similar to promoters [117-120]. The appearance of these features correlates with enhancer activation in certain cells $[119,121,122]$. Moreover, such enhancers and insulators can be transcribed to yield unstable noncoding RNAs. The functional significance of their transcription is a matter of discussion $[119,122$, 123].

Remodeling of nucleosomal particles during transcription elongation. Nucleosomal particles provide an obstacle for elongating RNA polymerase II in vitro [124, 125]. In vivo, histone chaperones and chromatin remodeling complexes improve the efficiency of elongation [126, 127], facilitating local partial nucleosome disassembly in front of the polymerase. Active transcription alters the regular nucleosome arrangement along the transcription unit, and the alteration may have adverse consequences for the cell, e. g., activating cryptic promoters (see below) [128]. Special mechanisms work to ensure correct chromatin assembly behind the passing elongation complexes [127, 128]. As the elongating RNA polymerase II complex progresses along nucleosomal DNA, one of the $\mathrm{H} 2 \mathrm{~A}-\mathrm{H} 2 \mathrm{~B}$ dimers dissociates, while the residual histone hexamer remains associated with DNA $[124,129]$. This mechanism accounts for a higher exchange rate of $\mathrm{H} 2 \mathrm{~A}-\mathrm{H} 2 \mathrm{~B}$ dimers on transcribed genes $[130,131]$. The exchange rate of the total nucleosome core increases with increasing transcription intensity, indicating that $(\mathrm{H} 3-\mathrm{H} 4)_{2}$ tetra- 
mers can also dissociate when elongating complexes pass frequently $[130,132,133]$. H2A-H2B dimer exchange probably involves the Asf1, Nap1, Spt6, and FACT histone chaperones, which act together with the SWI/SNF and RSC chromatin remodeling complexes [134-139]. Histone acetyltransferases PCAF and Elp3, which stimulate the function of chromatin remodeling complexes, specifically interact with elongating RNA polymerase II [140, 141]. SAGA and NuA4 are also recruited to transcription units along with the elongating complex to stimulate nucleosome displacement [142, 143].

On the other hand, nucleosome destabilization in transcribed regions increases probabilities of spontaneous formation of NDRs. Some of them may happen in DNA regions allowing transcription initiation [144147]. These regions are known as the cryptic promoters, and several mechanisms work to repress their activity. An important role is played by the Chd 1 and Isw 1 chromatin remodeling complexes, which maintain regular nucleosome spacing in transcribed regions [148151]. The interaction of $\mathrm{H} 2 \mathrm{~A}-\mathrm{H} 2 \mathrm{~B}$ dimers with the Asf1, Nap1, Spt6, and FACT chaperones facilitates the restoration of a nucleosomal octamer as soon as the polymerase has passed. In addition, dynamic acetylated nucleosomes are stabilized as Rpd3, Hos2, and Hda1 histone deacetylases are recruited to transcribed regions $[152,153]$. The Rpd3S deacetylation complex plays a key role in the process. RpdS3 is recruited by the Ser2phosphorylated C-terminal region of elongating RNA polymerase II $[152,153]$. Rpd3S activity is higher on H3K36me3-containing nucleosomes, which interact with the Eaf3 and Rco1 subunits of the complex via the Chromo and PHD domains [152]. H3K36 trimethylation, which recruits histone deacetylases, is catalyzed by Set2 histone methyltransferase, which also interacts with the Ser2-phosphorylated C-terminal domain of RNA polymerase II $[154,155]$. Thus, the modification provides a specific mark for the bodies of actively transcribed eukaryotic genes [156, 157] and ensures that low-level histone acetylation is restored in gene bodies as soon as the transcription complex has passed [128].

Internucleosomal interactions and the regulation of transcription. A number of modifications occurring in canonical histones and the presence of some variant histones affect, to a certain extent, the strength of inter- nucleosomal interactions. The modifications modulate the chromatin packaging and thereby act as an important factor regulating gene expression. When nucleosomal particles that strengthen the internucleosomal contacts are incorporated in chromatin, chromatin is condensed and DNA becomes less accessible to transcription machinery, while nucleosome modifications that hinder the internucleosomal interactions facilitate a loosening of chromatin and activation of its genes. The latter group of modifications includes H4K16 acetylation, which prevents the N-terminal domain of histone $\mathrm{H} 4$ from interacting with the acidic patch of the neighbor nucleosome. Chromatin composed of H4K16ac-containing nucleosomes cannot produce $30-\mathrm{nm}$ fibers in vitro [158$160]$ and is probably depleted of lateral interactions with other nucleosomal fibers in vivo. Nucleosome acetylation at other lysines can also affect in part the stability of internucleosomal interactions [161]. Local decondensation is possibly a mechanism that sustains the activator effect of acetylation on regulatory DNA elements. A similar effect is known for the incorporation of variant histone H2A.Bbd. This variant histone lacks the amino acid residues that are involved in the formation of the negatively charged surface (acidic patch) to interact with H4K16 [162]. Paradoxically, variant histone H2A.Z, which usually colocalizes with NDRs, allows a greater acidic patch area as compared with canonical histone $\mathrm{H} 2 \mathrm{~A}$, thus strengthening the internucleosomal contacts $[163,164]$.

A special group of histone modifications includes H3K9me3 and H3K27me3. Nucleosomes with these modifications recruit specific architecture proteins, which facilitate a denser chromatin packaging. The resulting condensed chromatin clusters at the periphery of the nucleus, in the perinucleolar region, and nucleoplasmic foci known as the chromocenters. Chromatin of denser regions was termed heterochromatin as opposed to less compact euchromatin [165].

H3K9me3 binds with heterochromatin protein 1 (HP1). HP1 is highly conserved, and its homologs are found in the majority of eukaryotes with the exception of budding yeasts [166], where a similar function is performed by the SIR proteins [167]. HP1 binds to $\mathrm{H} 3 \mathrm{~K} 9 \mathrm{me} 3$ via its chromodomain, which is in the $\mathrm{N}$-terminal region of the protein. The $\mathrm{C}$-terminal region of HP1 harbors the so-called chromoshadow domain, 
which provides for HP1 oligomerization [168]. Thus, HP1-mediated lateral interactions between $\mathrm{H} 3 \mathrm{~K} 9 \mathrm{me} 3-$ containing nucleosomes lead to chromatin condensation [169]. In addition, HP1 is capable of recruiting histone methyltransferases Suv39h1/2 and SETDB1, which are responsible for $\mathrm{H} 3 \mathrm{~K} 9$ trimethylation [170]. The resulting positive feedback is one of the mechanisms spreading the «histone code signal» to produce extended H3K9me3-enriched domains [171, 172]. Heterochromatin, which contains highly repetitive DNA and is enriched in $\mathrm{H} 3 \mathrm{~K} 9 \mathrm{me} 3$ and HP1, occurs in pericentric and subtelomeric regions in the majority of eukaryotes. However, it should be noted that neither HP1 $[173,174]$ nor H3K9 trimethylation [175] is essential for maintaining the heterochromatic chromocenters containing pericentric DNA. In addition, H3K9me3 domains that usually correspond to individual silent genes occur in chromosome arms. For instance, more than 10,000 H3K9me3-enriched domains with a median size of approximately $7 \mathrm{~kb}$ were observed in human embryonic stem cells (hESCs). Similar domains are about twice as large in fibroblasts [176]. Genome-wide studies identified the so-called LOCK (large organized chromatin $\mathrm{K} 9$ modification) domains, which are extended $(\sim 100 \mathrm{~kb})$ genome segments enriched in histone $\mathrm{H} 3$ di- or trimethylated at $\mathrm{K} 9$ [177].

$\mathrm{H} 3 \mathrm{~K} 27 \mathrm{me} 3$ is another conserved histone modification characteristic of eukaryotic heterochromatin [178]. The modification is often associated with facultative heterochromatin on genes - master regulators of development $[178,179]$. The H3K27me3 establishment and mechanism of action are closely associated with Polycomb group (PcG) proteins. PcG proteins are components of several complexes, of which PRC1 and PRC2 are best understood. PRC2 uses its component histone methyltransferase EZH2 to trimethylate histone $\mathrm{H} 3$ at $\mathrm{K} 27$. PRC1 binds to H3K27me3 and is thereby associated with sites of PRC2 activity [180]. In Drosophila, PRC2 is recruited to target genes by PRE elements (Polycomb response elements) which harbor consensus binding sites for several repressor factors interacting with PRC2 [181-183]. In vertebrates, the mechanism recruiting PRC2 to target genes is not fully understood [180]. An important role in the process is most likely played by $\mathrm{CpG}$ islands, where the promoters of genes targeted by PcG complexes mostly occur in vertebrates
$[184,185]$. These are usually the promoters of genes involved in maintaining pluripotency and master regulators of differentiation.

In embryonic stem cells, H3K27me3 colocalizes with the activating mark $\mathrm{H} 3 \mathrm{~K} 4 \mathrm{me} 3$ in the promoters of master regulators of differentiation to produce the socalled bivalent promoters [157]. Depending on the cell lineage, one of the marks is removed during differentiation, and if it is $\mathrm{H} 3 \mathrm{~K} 27 \mathrm{me} 3$ the gene is activated [157, 186]. A specific recruitment of PRC2 to target promoters was observed in plants, Arabidopsis thaliana in particular, but a consensus similar to Drosophila PRE was not identified [187].

The mechanism of promoter repression via $\mathrm{H} 3 \mathrm{~K} 27 \mathrm{me} 3$ and the PRC complexes is presumably related to the fact that, like HP1, PRC1 causes chromatin compaction to prevent free access of transcription factors to the genes involved [188-190]. According to classical views, heterochromatin is a more compact form of chromatin, and its compaction prevents heterochromatin DNA from being accessed by transcription machinery and thereby facilitates repression of heterochromatic genes. However, there is evidence that accessibility to large protein factors is similar between euchromatin and heterochromatin. For instance, the genome is more or less uniformly accessible to Dam methylation regardless of the heterochromatin nature of particular regions in Caenorhabditis elegans and S. cerevisiae [191, 192]. Transcription factors expressed artificially display no preference in binding to their sites in heterochromatin or euchromatin [191, 193]. Only molecular complexes of more than $1 \mathrm{MDa}$ are specifically excluded from heterochromatic regions according to microscopic studies [194-197].

Accessibility of heterochromatin or even more compact chromatin of metaphase chromosomes to diffusion of large protein complexes is probably related to the dynamic character of internucleosomal interactions, as assumed in the molten polymer model (see above). Owing to this dynamic character, individual nucleosomal particles can locally move relative to each other in the threedimensional nuclear space and periodically create channels to allow migration of protein complexes within compact chromatin domains $[33,197]$.

Transcriptional activity was recently demonstrated for the majority of Drosophila genes located in HP1- 
enriched pericentric heterochromatin [193, 198, 199]. As for genes repressed by the Polycomb complexes, it was found that a preinitiation complex is assembled and transcription initiated on their promoters in both Drosophila and mammalian cells, but elongation is blocked [200-202]. Thus, none of the most important types of eukaryotic heterochromatin prevents access to chromatin for transcription machinery. Then what is the role of chromatin compaction? The role is explained by the model that architecture proteins, such as SIR and HP1, and the PRC1 complex do not act to restrict access of activator factors to DNA, but rather function to create nuclear compartments with a high concentration of inhibitory factors, which ensure repression via other mechanisms [203, 204]. In the case of Polycomb-dependent repression, the mechanism possibly consists in PRC1mediated recruitment of RING1b ubiquitin ligase, which ubuquitinates histone $\mathrm{H} 2 \mathrm{~A}$ at $\mathrm{K} 119$, to promoters. The modification stabilizes the interaction of $\mathrm{H} 2 \mathrm{~A}-\mathrm{H} 2 \mathrm{~B}$ dimers with $(\mathrm{H} 3-\mathrm{H} 4)_{2}$ tetramers, and the elongating RNA polymerase complex cannot pass through these nucleosomes [18, 205]. In addition, a compact arrangement of repressed genome regions in the nucleus makes it possible to limit free diffusion of inhibitory factors in the nuclear space, preventing their nonspecific activity [206]. Well-known examples of such compact regions are provided by peripheral and perinucleolar heterochromatin, chromocenters, and PcG bodies [190, 204, 207, 208].

Conclusions. The structure of nucleosomal particles and its changes that accompany transcriptional activation or repression have been studied for almost half a century. This level of chromatin packaging is the most fully understood. However, several basic shifts occurred in the apparently firm views of nucleosomes and internucleosomal interactions in the past decade. Among these mini revolutions, the 30-nm fiber as an important level of chromatin packaging was rejected and changes were made to the classical views of the heterochromatin structure and the mechanisms of heterochromatic gene silencing. A drift from focusing on one or a few model loci to probing the chromatin organization on a genome-wide scale is one of the main trends in recent studies of the lower levels of eukaryotic DNA packaging. Another trend is collating the genome-wide maps of several epigenetic features, primarily the distributions of histone modifications, variant histones, and NDRs. Both of the trends are implemented in large-scale collaboration projects, of which ENCODE and modENCODE are the best known. A combination of the resulting data sets with information obtained by «C» methods for the spatial organization of chromatin [209-211] and highresolution microscopy findings will probably yield a comprehensive picture of DNA packaging in the nearest future and will help to better understand how the packaging mode is related to functional processes occurring in the cell nucleus.

Acknowledgements. This work was supported by the Russian Science Foundation (grant 14-14-01088).

Нуклеосомна упаковка евкаріотної ДНК і регуляція транскрипції

А. К. Голов, С. В. Разін, А. А. Гаврилов

Резюме

Ядра евкаріотних клітин містять геномну ДНК, лінійні розміри якої у десятки тисяч разів перевищують їхній діаметр. Багато в чому такий високий ступінь компактизації забезпечується упаковкою ДНК у хроматин, ключовим етапом якої є намотування ДНК на нуклеосомні глобули. Октамер гістонів, які складають нуклеосомну глобулу, взаємодіє з ДНК за посередниитвом електростатичних контактів. ДНК-гістонові взаємодії достатньо міџні і утруднюють доступ до нуклеосомної ДНК багатьох ферментів і транскрипиійних факторів. У той же час наявність нуклеосом не перешкоджає проходженню транскрипиії та інших проиесів, пов 'язаних з реалізачією генетичних функиій ДНК. В огляді розглянуто структуру і розмаїття нуклеосом та їхню центральну роль у регуляиії транскрипиії. Особливу увагу приділено значенню міжнуклеосомних взаємодій у забезпеченні доступності геному для транскрипиійної машинерії, а також регульованому видаленню нуклеосом з регуляторних елементів і транскрипиійних одиниць в прочесі елонгаџії транскрипиії.

Ключові слова: хроматин, модифікації гістонів, нуклеосома, транскрипиія.

Нуклеосомная упаковка эукариотической ДНК

и регуляция транскрипции

А. К. Голов, С. В. Разин, А. А. Гаврилов

Резюме

Ядра эукариотических клеток содержат геномную ДНК, линейные размеры которой в десятки тысяч раз превышают их диаметр. Во многом такая высокая степень компактизации обеспечивается упаковкой ДНК в хроматин, ключевым этапом которой является наматывание ДНК на нуклеосомные глобуль. Октамер гистонов, составляющих нуклеосомную глобулу, взаимодействует с ДНК посредством электростатических контактов. ДНКгистоновые взаимодействия достаточно прочны и затрудняют доступ к нуклеосомной ДНК многих ферментов и транскрипционных факторов. В то же время наличие нуклеосом не препятствует прохождению транскрипиии и других процессов, связанных с реализацией генетических функиий ДНК. В настоящем обзоре рассмотрены структура и многообразие нуклеосом и их иентраль- 
ная роль в регуляции транскрипции. Особое внимание уделено значению межнуклеосомных взаимодействий в обеспечении доступности генома для транскрипционной машинерии и регулируемому удалению нуклеосом с регуляторных элементов и транскрипционных единиц в процессе элонгации транскрипции.

Ключевые слова: хроматин, модификачии гистонов, нуклеосома, транскрипция.

\section{REFERENCES}

1. Talbert PB, Ahmad K, Almouzni G, et al. A unified phylogenybased nomenclature for histone variants. Epigenetics Chromatin. 2012;5:7.

2. Simpson RT, Stafford $D W$. Structural features of a phased nucleosome core particle. Proc Natl Acad Sci US A. 1983;80(1):51-5.

3. Allfrey $V G$, Mirsky AE. Structural modifications of histones and their possible role in the regulation of RNA synthesis. Science. 1964;144(3618):559.

4. Luger K, Richmond TJ. DNA binding within the nucleosome core. Curr Opin Struct Biol. 1998;8(1):33-40.

5. Andrews AJ, Luger K. Nucleosome structure(s) and stability: variations on a theme. Annu Rev Biophys. 2011;40:99-117.

6. Kornberg RD. Chromatin structure: a repeating unit of histones and DNA. Science. 1974;184(4139):868-71.

7. Davey CA, Sargent DF, Luger K, Maeder AW, Richmond TJ. Solvent mediated interactions in the structure of the nucleosome core particle at 1.9 a resolution. J Mol Biol. 2002;319(5):1097-113.

8. van Holde KE. Chromatin. New York, Springer, 1989; 497 p.

9. Bednar J, Horowitz RA, Grigoryev SA, et al. Nucleosomes, linker DNA, and linker histone form a unique structural motif that directs the higher-order folding and compaction of chromatin. Proc Natl Acad Sci U S A. 1998;95(24):14173-8.

10. Woodcock CL. Chromatin architecture. Curr Opin Struct Biol. 2006;16(2):213-20.

11. Talbert $P B$, Henikoff $S$. Chromatin: packaging without nucleosomes. Curr Biol. 2012;22(24):R1040-3.

12. Balhorn R. The protamine family of sperm nuclear proteins. Genome Biol. 2007;8(9):227.

13. Suganuma T, Workman JL. Signals and combinatorial functions of histone modifications. Annu Rev Biochem. 2011;80:473-99.

14. Rothbart $S B$, Strahl BD. Interpreting the language of histone and DNA modifications. Biochim Biophys Acta. 2014;1839 (8):627-43.

15. Sidoli S, Cheng L, Jensen ON. Proteomics in chromatin biology and epigenetics: Elucidation of post-translational modifications of histone proteins by mass spectrometry. J Proteomics. 2012;75 (12):3419-33.

16. Zhang $S$, Roche $K$, Nasheuer HP, Lowndes NF. Modification of histones by sugar $\beta$-N-acetylglucosamine (GlcNAc) occurs on multiple residues, including histone $\mathrm{H} 3$ serine 10 , and is cell cycle-regulated. J Biol Chem. 2011;286(43):37483-95.

17. Tan $M$, Luo H, Lee $S$, et al. Identification of 67 histone marks and histone lysine crotonylation as a new type of histone modification. Cell. 2011;146(6):1016-28.

18. Endoh M, Endo TA, Endoh T, et al. Histone H2A mono-ubiquitination is a crucial step to mediate $\mathrm{PRC1}$-dependent repression of developmental genes to maintain ES cell identity. PLoS Genet. 2012;8(7):e1002774.

19. Steger DJ, Lefterova MI, Ying L, et al. DOT1L/KMT4 recruitment and H3K79 methylation are ubiquitously coupled with gene transcription in mammalian cells. Mol Cell Biol. 2008;28(8): 2825-39.
20. Brown DT, Alexander BT, Sittman DB. Differential effect of H1 variant overexpression on cell cycle progression and gene expression. Nucleic Acids Res. 1996;24(3):486-93.

21. Jin C, Zang C, Wei G, et al. H3.3/H2A.Z double variant-containing nucleosomes mark «nucleosome-free regions» of active promoters and other regulatory regions. Nat Genet. 2009;41(8): 941-5.

22. Ioudinkova ES, Barat A, Pichugin A, et al. Distinct distribution of ectopically expressed histone variants $\mathrm{H} 2 \mathrm{~A}$.Bbd and $\mathrm{MacroH} 2 \mathrm{~A}$ in open and closed chromatin domains. PLoS One. 2012;7(10): e47157.

23. Tolstorukov MY, Goldman JA, Gilbert C, Ogryzko V, Kingston $R E$, Park PJ. Histone variant $\mathrm{H} 2 \mathrm{~A}$. Bbd is associated with active transcription and mRNA processing in human cells. Mol Cell. 2012;47(4):596-607.

24. Talbert PB, Henikoff S. Histone variants - ancient wrap artists of the epigenome. Nat Rev Mol Cell Biol. 2010;11(4):264-75.

25. Finch JT, Klug A. Solenoidal model for superstructure in chromatin. Proc Natl Acad Sci U S A. 1976;73(6):1897-901.

26. Li G, Reinberg D. Chromatin higher-order structures and gene regulation. Curr Opin Genet Dev. 2011;21(2):175-86.

27. Woodcock CL, Frado LL, Rattner JB. The higher-order structure of chromatin: evidence for a helical ribbon arrangement. $J$ Cell Biol. 1984;99(1 Pt 1):42-52.

28. Dorigo B, Schalch T, Kulangara A, Duda S, Schroeder RR, Richmond TJ. Nucleosome arrays reveal the two-start organization of the chromatin fiber. Science. 2004;306(5701):1571-3.

29. Schalch T, Duda S, Sargent DF, Richmond TJ. X-ray structure of a tetranucleosome and its implications for the chromatin fibre. Nature. 2005;436(7047):138-41.

30. van Holde K, Zlatanova J. Chromatin fiber structure: Where is the problem now? Semin Cell Dev Biol. 2007;18(5):651-8.

31. Eltsov M, Maclellan KM, Maeshima K, Frangakis AS, Dubochet $J$. Analysis of cryo-electron microscopy images does not support the existence of 30-nm chromatin fibers in mitotic chromosomes in situ. Proc Natl Acad Sci U S A. 2008;105(50):19732-7.

32. Maeshima $K$, Hihara $S$, Takata $H$. New insight into the mitotic chromosome structure: irregular folding of nucleosome fibers without 30-nm chromatin structure. Cold Spring Harb Symp Quant Biol. 2010;75:439-44.

33. Joti Y, Hikima T, Nishino Y, et al. Chromosomes without a 30nm chromatin fiber. Nucleus. 2012;3(5):404-10.

34. Razin SV, Gavrilov AA. Chromatin without the 30-nm fiber: constrained disorder instead of hierarchical folding. Epigenetics 2014;9(5):653-7.

35. Maeshima K, Imai R, Tamura S, Nozaki T. Chromatin as dynamic 10-nm fibers. Chromosoma. 2014;123(3):225-37.

36. Rando OJ, Ahmad K. Rules and regulation in the primary structure of chromatin. Curr Opin Cell Biol. 2007;19(3):250-6.

37. Campos EI, Reinberg D. Histones: annotating chromatin. Annu Rev Genet. 2009;43:559-99.

38. Wang J, Zhuang J, Iyer $S$, et al. Sequence features and chromatin structure around the genomic regions bound by 119 human transcription factors. Genome Res. 2012;22(9):1798-812.

39. Thurman RE, Rynes E, Humbert $R$, et al. The accessible chromatin landscape of the human genome. Nature. 2012;489(7414): 75-82.

40. Elgin SC. DNAase I-hypersensitive sites of chromatin. Cell. 1981;27(3 Pt 2):413-5.

41. Gross DS, Garrard WT. Nuclease hypersensitive sites in chromatin. Annu Rev Biochem. 1988;57:159-97.

42. Felsenfeld G, Boyes J, Chung J, Clark D, Studitsky V. Chromatin structure and gene expression. Proc Natl Acad Sci U S A 1996;93(18):9384-8. 
43. Boyle AP, Song L, Lee BK, et al. High-resolution genome-wide in vivo footprinting of diverse transcription factors in human cells. Genome Res. 2011;21(3):456-64.

44. John S, Sabo PJ, Thurman RE, et al. Chromatin accessibility predetermines glucocorticoid receptor binding patterns. Nat Genet. 2011;43(3):264-8.

45. Kaplan T, Li XY, Sabo PJ, et al. Quantitative models of the mechanisms that control genome-wide patterns of transcription factor binding during early Drosophila development. PLoS Genet. 2011;7(2):e1001290

46. Li XY, Thomas S, Sabo PJ, Eisen MB, Stamatoyannopoulos JA, Biggin $M D$. The role of chromatin accessibility in directing the widespread, overlapping patterns of Drosophila transcription factor binding. Genome Biol. 2011;12(4):R34

47. Pique-Regi R, Degner JF, Pai AA, Gaffney DJ, Gilad Y, Pritchard $J K$. Accurate inference of transcription factor binding from DNA sequence and chromatin accessibility data. Genome Res. 2011;21(3):447-55

48. Struhl K. Fundamentally different logic of gene regulation in eukaryotes and prokaryotes. Cell. 1999;98(1):1-4

49. Schnitzler GR. Control of nucleosome positions by DNA sequence and remodeling machines. Cell Biochem Biophys. 2008;51 (2-3):67-80

50. Cairns BR. The logic of chromatin architecture and remodelling at promoters. Nature. 2009;461(7261):193-8

51. Mavrich TN, Ioshikhes IP, Venters BJ, et al. A barrier nucleosome model for statistical positioning of nucleosomes throughout the yeast genome. Genome Res. 2008;18(7):1073-83.

52. Maier VK, Chioda M, Becker PB. ATP-dependent chromatosome remodeling. Biol Chem. 2008;389(4):345-52.

53. Clapier CR, Cairns BR. The biology of chromatin remodeling complexes. Annu Rev Biochem. 2009;78:273-304.

54. Kaplan N, Moore IK, Fondufe-Mittendorf Y, et al. The DNA-encoded nucleosome organization of a eukaryotic genome. Nature. 2009;458(7236):362-6.

55. Segal E, Widom J. Poly(dA:dT) tracts: major determinants of nucleosome organization. Curr Opin Struct Biol. 2009;19(1): $65-71$.

56. Lee $W$, Tillo $D$, Bray $N$, et al. A high-resolution atlas of nucleosome occupancy in yeast. Nat Genet. 2007;39(10):1235-44.

57. Struhl K. Naturally occurring poly(dA-dT) sequences are upstream promoter elements for constitutive transcription in yeast. Proc Natl Acad Sci U S A. 1985;82(24):8419-23.

58. Badis $G$, Chan ET, van Bakel $H$, et al. A library of yeast transcription factor motifs reveals a widespread function for Rsc3 in targeting nucleosome exclusion at promoters. Mol Cell. 2008;32 (6):878-87.

59. Burd CJ, Archer TK. Chromatin architecture defines the glucocorticoid response. Mol Cell Endocrinol. 2013;380(1-2):25-31.

60. Hartley PD, Madhani HD. Mechanisms that specify promoter nucleosome location and identity. Cell. 2009;137(3):445-58.

61. Sherwood RI, Hashimoto T, O'Donnell CW, et al. Discovery of directional and nondirectional pioneer transcription factors by modeling DNase profile magnitude and shape. Nat Biotechnol. 2014;32(2):171-8.

62. Fascher KD, Schmitz J, Horz $W$. Role of trans-activating proteins in the generation of active chromatin at the PHO5 promoter in S. cerevisiae. EMBO J. 1990;9(8):2523-8.

63. Yudkovsky N, Logie C, Hahn S, Peterson CL. Recruitment of the SWI/SNF chromatin remodeling complex by transcriptional activators. Genes Dev. 1999;13(18):2369-74.

64. Zaret KS, Carroll JS. Pioneer transcription factors: establishing competence for gene expression. Genes Dev. 2011;25(21): $2227-41$.
65. Ho JW, Jung YL, Liu T, et al. Comparative analysis of metazoan chromatin organization. Nature. 2014;512(7515):449-52.

66. Shen Y, Yue F, McCleary DF, et al. A map of the cis-regulatory sequences in the mouse genome. Nature. 2012;488(7409):116-20.

67. Gerstein MB, Lu ZJ, Van Nostrand EL, et al. Integrative analysis of the Caenorhabditis elegans genome by the modENCODE project. Science. 2010;330(6012):1775-87.

68. modENCODE Consortium, Roy S, Ernst J, et al. Identification of functional elements and regulatory circuits by Drosophila modENCODE. Science. 2010;330(6012):1787-97.

69. Kasten M, Szerlong H, Erdjument-Bromage H, Tempst P, Werner $M$, Cairns BR. Tandem bromodomains in the chromatin remodeler RSC recognize acetylated histone $\mathrm{H} 3$ Lys14. EMBO J. 2004;23(6): 1348-59.

70. VanDemark AP, Kasten MM, Ferris E, Heroux A, Hill CP, Cairns $B R$. Autoregulation of the rsc 4 tandem bromodomain by gen 5 acetylation. Mol Cell. 2007;27(5):817-28.

71. Chatterjee N, Sinha D, Lemma-Dechassa M, Tan S, ShogrenKnaak MA, Bartholomew B. Histone $\mathrm{H} 3$ tail acetylation modulates ATP-dependent remodeling through multiple mechanisms Nucleic Acids Res. 2011;39(19):8378-91.

72. Ferreira H, Flaus A, Owen-Hughes T. Histone modifications influence the action of Snf2 family remodelling enzymes by different mechanisms. J Mol Biol. 2007;374(3):563-79.

73. Sterner DE, Berger SL. Acetylation of histones and transcription-related factors. Microbiol Mol Biol Rev. 2000;64(2) 435-59.

74. Strahl BD, Allis CD. The language of covalent histone modifications. Nature. 2000;403(6765):41-5.

75. Koutelou E, Hirsch CL, Dent SY. Multiple faces of the SAGA complex. Curr Opin Cell Biol. 2010;22(3):374-82.

76. Albert I, Mavrich TN, Tomsho LP, et al. Translational and rotational settings of H2A.Z nucleosomes across the Saccharomyces cerevisiae genome. Nature. 2007;446(7135):572-6.

77. Jin C, Felsenfeld $G$. Nucleosome stability mediated by histone variants H3.3 and H2A.Z. Genes Dev. 2007;21(12):1519-29.

78. Henikoff S. Nucleosome destabilization in the epigenetic regulation of gene expression. Nat Rev Genet. 2008;9(1):15-26.

79. Mizuguchi $G$, Shen $X$, Landry J, Wu WH, Sen $S$, Wu C. ATP-driven exchange of histone H2AZ variant catalyzed by SWR1 chromatin remodeling complex. Science. 2004;303(5656):343-8.

80. Ruhl DD, Jin J, Cai Y, et al. Purification of a human SRCAP complex that remodels chromatin by incorporating the histone variant H2A.Z into nucleosomes. Biochemistry. 2006;45(17): 5671-7.

81. Ranjan A, Mizuguchi G, FitzGerald PC, et al. Nucleosome-free region dominates histone acetylation in targeting SWR1 to promoters for H2A.Z replacement. Cell. 2013;154(6):1232-45.

82. Vermeulen $M$, Timmers HT. Grasping trimethylation of histone H3 at lysine 4. Epigenomics. 2010;2(3):395-406.

83. Ng HH, Robert F, Young RA, Struhl K. Targeted recruitment of Set 1 histone methylase by elongating Pol II provides a localized mark and memory of recent transcriptional activity. Mol Cell. 2003;11(3):709-19.

84. Shilatifard A. The COMPASS family of histone H3K4 methylases: mechanisms of regulation in development and disease pathogenesis. Annu Rev Biochem. 2012;81:65-95.

85. Jeronimo $C$, Bataille $A R$, Robert $F$. The writers, readers, and functions of the RNA polymerase II C-terminal domain code. Chem Rev. 2013;113(11):8491-522.

86. Lee JH, Skalnik DG. CpG-binding protein (CXXC finger protein 1) is a component of the mammalian Set1 histone H3-Lys4 methyltransferase complex, the analogue of the yeast Set1/ COMPASS complex. J Biol Chem. 2005;280(50):41725-31. 
87. Thomson JP, Skene PJ, Selfridge J, et al. CpG islands influence chromatin structure via the $\mathrm{CpG}$-binding protein Cfp1. Nature. 2010;464(7291):1082-6.

88. Taverna SD, Li H, Ruthenburg AJ, Allis CD, Patel DJ. How chromatin-binding modules interpret histone modifications: lessons from professional pocket pickers. Nat Struct Mol Biol. 2007; 14(11):1025-40.

89. Wysocka J, Swigut T, Xiao H, et al. A PHD finger of NURF couples histone $\mathrm{H} 3$ lysine 4 trimethylation with chromatin remodelling. Nature. 2006;442(7098):86-90.

90. Lee KK, Workman JL. Histone acetyltransferase complexes: one size doesn't fit all. Nat Rev Mol Cell Biol. 2007;8(4):284-95.

91. ENCODE Project Consortium. An integrated encyclopedia of DNA elements in the human genome. Nature. 2012;489(7414): 57-74.

92. Maston GA, Evans SK, Green MR. Transcriptional regulatory elements in the human genome. Annu Rev Genomics Hum Genet. 2006;7:29-59.

93. Visel A, Rubin EM, Pennacchio LA. Genomic views of distantacting enhancers. Nature. 2009;461(7261):199-205.

94. Vavouri T, McEwen GK, Woolfe A, Gilks WR, Elgar G. Defining a genomic radius for long-range enhancer action: duplicated conserved non-coding elements hold the key. Trends Genet. 2006; 22(1):5-10

95. Lettice LA, Heaney SJ, Purdie LA, et al. A long-range Shh enhancer regulates expression in the developing limb and fin and is associated with preaxial polydactyly. Hum Mol Genet. 2003;12 (14): $1725-35$

96. Sanyal A, Lajoie BR, Jain G, Dekker J. The long-range interaction landscape of gene promoters. Nature. 2012;489(7414): $109-13$.

97. Kikuta H, Laplante M, Navratilova P, et al. Genomic regulatory blocks encompass multiple neighboring genes and maintain conserved synteny in vertebrates. Genome Res. 2007;17(5):545-55.

98. Birnbaum RY, Clowney EJ, Agamy O, et al. Coding exons function as tissue-specific enhancers of nearby genes. Genome Res. 2012;22(6):1059-68.

99. Heintzman ND, Hon GC, Hawkins RD, et al. Histone modifications at human enhancers reflect global cell-type-specific gene expression. Nature. 2009;459(7243):108-12.

100. Heinz S, Benner C, Spann N, et al. Simple combinations of lineage-determining transcription factors prime cis-regulatory elements required for macrophage and B cell identities. Mol Cell. 2010;38(4):576-89.

101. Calo E, Wysocka J. Modification of enhancer chromatin: what, how, and why? Mol Cell. 2013;49(5):825-37.

102. Svotelis A, Gevry N, Gaudreau L. Regulation of gene expression and cellular proliferation by histone H2A.Z. Biochem Cell Biol. 2009;87(1):179-88.

103. Creyghton MP, Cheng AW, Welstead GG, et al. Histone H3K27ac separates active from poised enhancers and predicts developmental state. Proc Natl Acad Sci USA. 2010;107(50):21931-6.

104. Rada-Iglesias A, Bajpai R, Swigut T, Brugmann SA, Flynn RA, Wysocka J. A unique chromatin signature uncovers early developmental enhancers in humans. Nature. 2011;470(7333):279-83.

105. Heintzman ND, Stuart RK, Hon G, et al. Distinct and predictive chromatin signatures of transcriptional promoters and enhancers in the human genome. Nat Genet. 2007;39(3):311-8.

106. Phillips-Cremins JE, Corces VG. Chromatin insulators: linking genome organization to cellular function. Mol Cell. 2013;50(4): 461-74.

107. Schoborg T, Labrador M. Expanding the roles of chromatin insulators in nuclear architecture, chromatin organization and genome function. Cell Mol Life Sci. 2014;71(21):4089-113.
108. Ulianov SV, Markova EN, Gavrilov AA, Razin SV. Insulators in vertebrates: regulatory mechanisms and chromatin structure. Biopolym Cell. 2012; 28(4):252-60.

109. Kirkland JG, Raab JR, Kamakaka RT. TFIIIC bound DNA elements in nuclear organization and insulation. Biochim Biophys Acta. 2013;1829(3-4):418-24.

110. Van Bortle K, Corces VG. tDNA insulators and the emerging role of TFIIIC in genome organization. Transcription. 2012;3(6):277-84.

111. Ong CT, Corces VG. CTCF: an architectural protein bridging genome topology and function. Nat Rev Genet. 2014;15(4):234-46.

112. Holwerda SJ, de Laat $W$. CTCF: the protein, the binding partners, the binding sites and their chromatin loops. Philos Trans $R$ Soc Lond B Biol Sci. 2013;368(1620):20120369.

113. Kyrchanova $O$, Georgiev $P$. Chromatin insulators and long-distance interactions in Drosophila. FEBS Lett. 2014;588(1):8-14.

114. Gurudatta $B V$, Corces VG. Chromatin insulators: lessons from the fly. Brief Funct Genomic Proteomic. 2009;8(4):276-82.

115. Ernst J, Kellis M. Discovery and characterization of chromatin states for systematic annotation of the human genome. Nat Biotechnol. 2010;28(8):817-25.

116. Wendt KS, Yoshida K, Itoh T, et al. Cohesin mediates transcriptional insulation by CCCTC-binding factor. Nature. 2008;451 (7180):796-801.

117. Hon $G$, Wang $W$, Ren $B$. Discovery and annotation of functional chromatin signatures in the human genome. PLoS Comput Biol. 2009;5(11):e1000566.

118. Raab JR, Kamakaka RT. Insulators and promoters: closer than we think. Nat Rev Genet. 2010;11(6):439-46.

119. De Santa F, Barozzi I, Mietton F, et al. A large fraction of extragenic RNA pol II transcription sites overlap enhancers. PLoS Biol. 2010;8(5):e1000384.

120. Koch F, Fenouil R, Gut M, et al. Transcription initiation platforms and GTF recruitment at tissue-specific enhancers and promoters. Nat Struct Mol Biol. 2011;18(8):956-63.

121. Pekowska A, Benoukraf T, Zacarias-Cabeza J, et al. H3K4 trimethylation provides an epigenetic signature of active enhancers. EMBO J. 2011;30(20):4198-210.

122. Koch F, Andrau JC. Initiating RNA polymerase II and TIPs as hallmarks of enhancer activity and tissue-specificity. Transcription. 2011;2(6):263-8.

123. Natoli G, Andrau JC. Noncoding transcription at enhancers: general principles and functional models. Аnnu Rev Genet. 2012; 46:1-19.

124. Kireeva ML, Walter $W$, Tchernajenko V, Bondarenko V, Kashlev M, Studitsky VM. Nucleosome remodeling induced by RNA polymerase II: loss of the $\mathrm{H} 2 \mathrm{~A} / \mathrm{H} 2 \mathrm{~B}$ dimer during transcription. Mol Cell. 2002;9(3):541-52.

125. Izban MG, Luse DS. Transcription on nucleosomal templates by RNA polymerase II in vitro: inhibition of elongation with enhancement of sequence-specific pausing. Genes Dev. 1991;5 (4):683-96.

126. Singh J, Padgett RA. Rates of in situ transcription and splicing in large human genes. Nat Struct Mol Biol. 2009;16(11):1128-33.

127. Selth LA, Sigurdsson $S$, Svejstrup JQ. Transcript elongation by RNA polymerase II. Annu Rev Biochem. 2010;79:271-93.

128. Smolle M, Workman JL. Transcription-associated histone modifications and cryptic transcription. Biochim Biophys Acta. 2013; 1829(1):84-97.

129. Belotserkovskaya R, Oh S, Bondarenko VA, Orphanides G, Studitsky VM, Reinberg D. FACT facilitates transcription-dependent nucleosome alteration. Science. 2003;301(5636):1090-3.

130. Thiriet $C$, Hayes $J J$. Replication-independent core histone dynamics at transcriptionally active loci in vivo. Genes Dev. 2005; 19(6):677-82. 
131. Jamai A, Imoberdorf RM, Strubin M. Continuous histone H2B and transcription-dependent histone $\mathrm{H} 3$ exchange in yeast cells outside of replication. Mol Cell. 2007;25(3):345-55.

132. Dion MF, Kaplan T, Kim M, Buratowski S, Friedman N, Rando $O J$. Dynamics of replication-independent histone turnover in budding yeast. Science. 2007;315(5817):1405-8.

133. Rufiange A, Jacques PE, Bhat W, Robert F, Nourani A. Genome-wide replication-independent histone $\mathrm{H} 3$ exchange occurs predominantly at promoters and implicates H3 K56 acetylation and Asf1. Mol Cell. 2007;27(3):393-405.

134. Adkins $M W$, Tyler JK. The histone chaperone Asflp mediates global chromatin disassembly in vivo. J Biol Chem. 2004;279 (50):52069-74.

135. Schwabish MA, Struhl K. Asf1 mediates histone eviction and deposition during elongation by RNA polymerase II. Mol Cell. 2006;22(3):415-22.

136. Walfridsson J, Khorosjutina O, Matikainen P, Gustafsson CM, Ekwall $K$. A genome-wide role for CHD remodelling factors and Nap1 in nucleosome disassembly. EMBO J. 2007;26(12): 2868-79.

137. Robinson KM, Schultz MC. Replication-independent assembly of nucleosome arrays in a novel yeast chromatin reconstitution system involves antisilencing factor Asflp and chromodomain protein Chd1p. Mol Cell Biol. 2003;23(22):7937-46.

138. Zlatanova J, Seebart C, Tomschik M. Nap1: taking a closer look at a juggler protein of extraordinary skills. FASEB J. 2007;21 (7):1294-310.

139. Kuryan BG, Kim J, Tran NN, et al. Histone density is maintained during transcription mediated by the chromatin remodeler $\mathrm{RSC}$ and histone chaperone NAP1 in vitro. Proc Natl Acad Sci US A. 2012;109(6):1931-6.

140. Wittschieben BO, Otero $G$, de Bizemont $T$, et al. A novel histone acetyltransferase is an integral subunit of elongating RNA polymerase II holoenzyme. Mol Cell. 1999;4(1):123-8.

141. Cho H, Orphanides $G$, Sun $X$, et al. A human RNA polymerase II complex containing factors that modify chromatin structure. Mol Cell Biol. 1998;18(9):5355-63.

142. Govind CK, Zhang F, Qiu H, Hofmeyer K, Hinnebusch AG. Gcn5 promotes acetylation, eviction, and methylation of nucleosomes in transcribed coding regions. Mol Cell. 2007;25(1):31-42.

143. Ginsburg DS, Govind CK, Hinnebusch $A G$. NuA4 lysine acetyltransferase Esa1 is targeted to coding regions and stimulates transcription elongation with Gen5. Mol Cell Biol. 2009;29(24): 6473-87.

144. Kaplan CD, Laprade L, Winston F. Transcription elongation factors repress transcription initiation from cryptic sites. Science. 2003;301(5636):1096-9.

145. Cheung V, Chua G, Batada NN, et al. Chromatin- and transcription-related factors repress transcription from within coding regions throughout the Saccharomyces cerevisiae genome. PLoS Biol. 2008;6(11):e277.

146. Li B, Gogol M, Carey M, Lee D, Seidel C, Workman JL. Combined action of PHD and chromo domains directs the Rpd3S HDAC to transcribed chromatin. Science. 2007;316(5827):1050-4.

147. Silva $A C, X u X$, Kim HS, et al. The replication-independent histone H3-H4 chaperones HIR, ASF1, and RTT106 cooperate to maintain promoter fidelity. J Biol Chem. 2012;287(3): 1709-18.

148. Gkikopoulos T, Schofield P, Singh V, et al. A role for Snf2-related nucleosome-spacing enzymes in genome-wide nucleosome organization. Science. 2011;333(6050):1758-60.

149. Hennig BP, Bendrin K, Zhou Y, Fischer T. Chd1 chromatin remodelers maintain nucleosome organization and repress cryptic transcription. EMBO Rep. 2012;13(11):997-1003.
150. Pointner J, Persson J, Prasad P, et al. CHD1 remodelers regulate nucleosome spacing in vitro and align nucleosomal arrays over gene coding regions in $S$. pombe. EMBO J. 2012;31(23): 4388-403.

151. Shim YS, Choi Y, Kang K, et al. Hrp3 controls nucleosome positioning to suppress non-coding transcription in eu- and heterochromatin. EMBO J. 2012;31(23):4375-87.

152. Govind CK, Qiu H, Ginsburg DS, et al. Phosphorylated Pol II CTD recruits multiple HDACs, including $\mathrm{Rpd} 3 \mathrm{C}(\mathrm{S})$, for methylation-dependent deacetylation of ORF nucleosomes. Mol Cell. 2010;39(2):234-46.

153. Drouin $S$, Laramee L, Jacques PE, Forest A, Bergeron M, Robert $F$. DSIF and RNA polymerase II CTD phosphorylation coordinate the recruitment of Rpd3S to actively transcribed genes. PLoS Genet. 2010;6(10):e1001173.

154. Krogan NJ, Kim M, Tong A, et al. Methylation of histone H3 by Set2 in Saccharomyces cerevisiae is linked to transcriptional elongation by RNA polymerase II. Mol Cell Biol. 2003;23(12): 4207-18.

155. Li B, Howe L, Anderson S, Yates JR 3rd, Workman JL. The Set2 histone methyltransferase functions through the phosphorylated carboxyl-terminal domain of RNA polymerase II. J Biol Chem. 2003;278(11):8897-903.

156. Bannister AJ, Schneider R, Myers FA, Thorne AW, Crane-Robinson $C$, Kouzarides T. Spatial distribution of di- and tri-methyl lysine 36 of histone $\mathrm{H} 3$ at active genes. J Biol Chem. 2005; 280(18): 17732-6.

157. Mikkelsen TS, Ku M, Jaffe DB, et al. Genome-wide maps of chromatin state in pluripotent and lineage-committed cells. Nature. 2007;448(7153):553-60.

158. Shogren-Knaak M, Ishii H, Sun JM, Pazin MJ, Davie JR, Peterson $C L$. Histone H4-K16 acetylation controls chromatin structure and protein interactions. Science. 2006;311(5762):844-7.

159. Robinson PJ, An W, Routh A, et al. $30 \mathrm{~nm}$ chromatin fibre decompaction requires both $\mathrm{H} 4-\mathrm{K} 16$ acetylation and linker histone eviction. J Mol Biol. 2008;381(4):816-25.

160. Allahverdi A, Yang R, Korolev N, et al. The effects of histone H4 tail acetylations on cation-induced chromatin folding and self-association. Nucleic Acids Res. 2011;39(5):1680-91.

161. Pepenella S, Murphy KJ, Hayes JJ. Intra- and inter-nucleosome interactions of the core histone tail domains in higher-order chromatin structure. Chromosoma. 2014;123(1-2):3-13.

162. Zhou J, Fan JY, Rangasamy D, Tremethick DJ. The nucleosome surface regulates chromatin compaction and couples it with transcriptional repression. Nat Struct Mol Biol. 2007;14(11):1070-6.

163. Greaves IK, Rangasamy D, Ridgway P, Tremethick DJ. H2A.Z contributes to the unique 3D structure of the centromere. Proc Natl Acad Sci U S A. 2007;104(2):525-30.

164. Fan JY, Rangasamy D, Luger K, Tremethick DJ. H2A.Z alters the nucleosome surface to promote HPlalpha-mediated chromatin fiber folding. Mol Cell. 2004;16(4):655-61.

165. Heitz E. Der Nachweis der Chromosomen. Z Bot. 1928;18: $625-81$.

166. Zeng $W$, Ball AR Jr, Yokomori K. HP1: heterochromatin binding proteins working the genome. Epigenetics. 2010;5(4):287-92.

167. Kueng S, Oppikofer M, Gasser SM. SIR proteins and the assembly of silent chromatin in budding yeast. Annu Rev Genet. 2013; 47:275-306.

168. Lachner M, O'Carroll D, Rea S, Mechtler K, Jenuwein T. Methylation of histone $\mathrm{H} 3$ lysine 9 creates a binding site for HP1 proteins. Nature. 2001;410(6824):116-20.

169. Canzio D, Chang EY, Shankar S, et al. Chromodomain-mediated oligomerization of HP1 suggests a nucleosome-bridging mechanism for heterochromatin assembly. Mol Cell. 20117;41(1):67-81. 
170. Fritsch L, Robin P, Mathieu JR, et al. A subset of the histone H3 lysine 9 methyltransferases Suv39h1, G9a, GLP, and SETDB1 participate in a multimeric complex. Mol Cell. 2010;37(1):46-56.

171. Schotta G, Ebert A, Krauss V, et al. Central role of Drosophila SU(VAR)3-9 in histone H3-K9 methylation and heterochromatic gene silencing. EMBO J. 2002;21(5):1121-31.

172. Groner AC, Meylan S, Ciuffi A, et al. KRAB-zinc finger proteins and KAP1 can mediate long-range transcriptional repression through heterochromatin spreading. PLoS Genet. 2010;6(3): e1000869.

173. Mateos-Langerak J, Brink MC, Luijsterburg MS, van der Kraan $I$, van Driel R, Verschure PJ. Pericentromeric heterochromatin domains are maintained without accumulation of HP1. Mol Biol Cell. 2007;18(4):1464-71.

174. Velichko AK, Kantidze OL, Razin SV. HP1 $\alpha$ is not necessary for the structural maintenance of centromeric heterochromatin. Epigenetics. 2011;6(3):380-7.

175. Peters AH, Kubicek S, Mechtler K, et al. Partitioning and plasticity of repressive histone methylation states in mammalian chromatin. Mol Cell. 2003;12(6):1577-89.

176. Hawkins RD, Hon GC, Lee LK, et al. Distinct epigenomic landscapes of pluripotent and lineage-committed human cells. Cell Stem Cell. 2010;6(5):479-91.

177. Wen B, Wu H, Shinkai Y, Irizarry RA, Feinberg AP. Large histone H3 lysine 9 dimethylated chromatin blocks distinguish differentiated from embryonic stem cells. Nat Genet. 2009;41(2): 246-50.

178. Margueron R, Reinberg $D$. The Polycomb complex PRC2 and its mark in life. Nature. 2011;469(7330):343-9.

179. Butenko Y, Ohad N. Polycomb-group mediated epigenetic mechanisms through plant evolution. Biochim Biophys Acta. 2011; 1809(8):395-406.

180. Di Croce L, Helin K. Transcriptional regulation by Polycomb group proteins. Nat Struct Mol Biol. 2013;20(10):1147-55.

181. Schwartz YB, Kahn TG, Nix DA, et al. Genome-wide analysis of Polycomb targets in Drosophila melanogaster. Nat Genet. 2006;38(6):700-5.

182. Tolhuis B, de Wit E, Muijrers I, et al. Genome-wide profiling of PRC1 and PRC2 Polycomb chromatin binding in Drosophila melanogaster. Nat Genet. 2006;38(6):694-9.

183. Negre N, Hennetin J, Sun LV, et al. Chromosomal distribution of PcG proteins during Drosophila development. PLoS Biol. 2006; 4(6): 170

184. Ku M, Koche RP, Rheinbay E et al. Genomewide analysis of PRC1 and PRC2 occupancy identifies two classes of bivalent domains. PLoS Genet. 2008;4(10):e1000242.

185. Lynch MD, Smith AJ, De Gobbi M, et al. An interspecies analysis reveals a key role for unmethylated $\mathrm{CpG}$ dinucleotides in vertebrate Polycomb complex recruitment. EMBO J. 2012;31 (2):317-29.

186. Cui K, Zang C, Roh TY, et al. Chromatin signatures in multipotent human hematopoietic stem cells indicate the fate of bivalent genes during differentiation. Cell Stem Cell. 2009;4(1):80-93.

187. Kohler $C$, Villar $C B$. Programming of gene expression by Polycomb group proteins. Trends Cell Biol. 2008;18(5):236-43.

188. Francis NJ, Kingston RE, Woodcock CL. Chromatin compaction by a polycomb group protein complex. Science. 2004;306 (5701):1574-7.

189. Simon JA, Kingston RE. Mechanisms of polycomb gene silencing: knowns and unknowns. Nat Rev Mol Cell Biol. 2009;10 (10):697-708.

190. Bantignies $F$, Cavalli $G$. Polycomb group proteins: repression in 3D. Trends Genet. 2011;27(11):454-64.

191. Chen L, Widom J. Mechanism of transcriptional silencing in yeast. Cell. 2005;120(1):37-48.
192. Sha K, Gu SG, Pantalena-Filho LC, et al. Distributed probing of chromatin structure in vivo reveals pervasive chromatin accessibility for expressed and non-expressed genes during tissue differentiation in C. elegans. BMC Genomics. 2010;11:465.

193. Filion GJ, van Bemmel JG, Braunschweig $U$, et al. Systematic protein location mapping reveals five principal chromatin types in Drosophila cells. Cell. 2010;143(2):212-24.

194. Verschure PJ, van der Kraan I, Manders EM, Hoogstraten D, Houtsmuller $A B$, van Driel R. Condensed chromatin domains in the mammalian nucleus are accessible to large macromolecules. EMBO Rep. 2003;4(9):861-6.

195. Gorisch SM, Lichter P, Rippe K. Mobility of multi-subunit complexes in the nucleus: accessibility and dynamics of chromatin subcompartments. Histochem Cell Biol. 2005;123(3):217-28.

196. Pack C, Saito K, Tamura M, Kinjo M. Microenvironment and effect of energy depletion in the nucleus analyzed by mobility of multiple oligomeric EGFPs. Biophys J. 2006;91(10):3921-36.

197. Hihara S, Pack CG, Kaizu K, et al. Local nucleosome dynamics facilitate chromatin accessibility in living mammalian cells. Cell Rep. 2012;2(6):1645-56.

198. Piacentini L, Fanti L, Negri R, et al. Heterochromatin protein 1 (HP1a) positively regulates euchromatic gene expression through RNA transcript association and interaction with hnRNPs in Drosophila. PLoS Genet. 2009;5(10):e1000670.

199. Riddle NC, Minoda A, Kharchenko PV, et al. Plasticity in patterns of histone modifications and chromosomal proteins in Drosophila heterochromatin. Genome Res. 2011;21(2):147-63.

200. Brookes E, de Santiago I, Hebenstreit D, et al. Polycomb associates genome-wide with a specific RNA polymerase II variant, and regulates metabolic genes in ESCs. Cell Stem Cell. 2012;10 (2):157-70.

201. Kanhere A, Viiri K, Araujo CC, et al. Short RNAs are transcribed from repressed polycomb target genes and interact with polycomb repressive complex-2. Mol Cell. 2010;38(5):675-88.

202. Enderle D, Beisel C, Stadler MB, Gerstung M, Athri P, Paro R. Polycomb preferentially targets stalled promoters of coding and noncoding transcripts. Genome Res. 2011;21(2):216-26.

203. Buhler M, Gasser SM. Silent chromatin at the middle and ends: lessons from yeasts. EMBO J. 2009;28(15):2149-61.

204. Towbin BD, Gonzalez-Sandoval A, Gasser SM. Mechanisms of heterochromatin subnuclear localization. Trends Biochem Sci. 2013;38(7):356-63

205. Stock JK, Giadrossi S, Casanova M, et al. Ring1-mediated ubiquitination of $\mathrm{H} 2 \mathrm{~A}$ restrains poised RNA polymerase II at bivalent genes in mouse ES cells. Nat Cell Biol. 2007;9(12):1428-35.

206. Taddei A, Van Houwe G, Nagai S, Erb I, van Nimwegen E, Gasser SM. The functional importance of telomere clustering: global changes in gene expression result from SIR factor dispersion. Genome Res. 2009;19(4):611-25.

207. Padeken J, Heun P. Nucleolus and nuclear periphery: velcro for heterochromatin. Curr Opin Cell Biol. 2014;28:54-60.

208. Pinheiro I, Margueron R, Shukeir N, et al. Prdm3 and Prdm16 are $\mathrm{H} 3 \mathrm{~K} 9 \mathrm{me} 1$ methyltransferases required for mammalian heterochromatin integrity. Cell. 2012;150(5):948-60.

209. Dekker J, Rippe K, Dekker M, Kleckner N. Capturing chromosome conformation. Science. 2002;295(5558):1306-11.

210. de Wit $E$, de Laat $W$. A decade of $3 C$ technologies: insights into nuclear organization. Genes Dev. 2012;26(1):11-24.

211. Gavrilov AA, Razin SV, Iarovaia OV. C-methods to study 3D organization of the eukaryotic genome. Biopolym Cell. 2012; 28(4):245-51. 